\title{
Study of Talents Training Mode of Modern Apprenticeship in the Higher Vocational Education
}

\author{
Jiang Bian, Xiaoyu Wang \\ Institute of Electrical and Electronic Engineering Kaifeng University; Kaifeng 475004, China
}

\begin{abstract}
From ancient to modern times, China has always been a nation that honors the teacher and respects his teaching. Teachers can not only propagate the doctrine, impart professional knowledge, and solve doubts, but also bear the greatest responsibility of training talents for social needs. The traditional apprenticeship is an extension of the farther-son relationship, and it is obvious that students and teachers need to follow the relevant rules strictly. Students just follow the teacher's learning skills, thus they can improve their self-cultivation and knowledge level. However, this "apprentice system" is more rigid and dogmatic, which makes our students lack flexibility and innovation. With the economic development, education is also booming. The emergence of the system makes students and teachers in a fixed educational institutions to learn and teach. What's more, modern apprenticeship system has also put more and more emphasis on the practice and the practicality of education. We all know that higher vocational education is mainly aimed at training students and teaching skills and technology for the need of talent market. Nowadays, there are many problems in cultivation of talents in vocational schools, for example the lack of professional teachers team and practice opportunity, and so on. Therefore, we must establish a scientific "modern apprenticeship system". This article will discuss the cultivation mode of "modern apprenticeship" through the existing problems in higher vocational education.
\end{abstract}

Keywords: Talent training; Apprenticeships; Higher vocational education.

\section{Introduction}

As the government has increased the importance of educational institutions, universities have established and played an important teaching role. Our education system is mainly divided into the elementary education, secondary education, higher education and adult education, and higher vocational education belongs to the higher education. It aims at training professional and technical personnel are to meet the needs of talent market. What we call the higher vocational education here is not same with the college education, because they have different educational purposes and play different role in educational system. Therefore, we must understand the main goal of higher vocational education in order that we can make a reasonable talent cultivation mode to realize education aim of vocational schools. In the education project, the teacher's role is to guide, educate and inspire. So, we must pay attention to the role of educators and implement reasonable mode of personnel training. The traditional mode of personnel training is the way that folk craftsmen guide and teach students to make crafts, and to learn the basic skills of learning. Now, higher vocational education is the legacy and development of traditional apprenticeship system, which is responsible for the cultivation of national professional talents. The higher vocational education regards practice as the main body, so we must attach importance to the practice of professional higher education. And we must pay attention to the disadvantages of practical education in higher vocational education.

\section{The Concept And Inheritance of Apprenticeship}

Apprenticeship mainly refers to the teacher-student relationship between the teacher and the student, which is a kind of education produced in the lower level of the productive forces. Next, I will briefly describe the main concepts and characteristics of apprenticeship.

\subsection{The definition of apprenticeship}

Apprentice is the student under the guidance of the master to process technical study and learning. The specific meaning of apprenticeship will be changed by time and place. Because that the official 
education in ancient China was not popular, so both of the private school and apprentice have risen. The content of apprenticeship is constantly enriched with the change of time. In a word, the apprentice system is the system that the apprentice learns from the teacher to form a special relationship. And now the higher vocational education is a system for the apprentice to follow and develop. Thus, the apprenticeship does not disappear over time, but shows in a different form.

\subsection{The characteristics of traditional apprenticeship}

Apprenticeship system is not same with what we call the educational system, and the former is developed on the premise of low productivity level and less emphasis on the education. So apprenticeship is the embodiment and carrier of productivity level, and it can express the social environment and local customs. And that is the reason why apprenticeship is regional. Apprenticeship is mainly oriented with the study of handicraft with rather strong practicability, and that apprentices learn skills from their master is to have specific skills and acquire certain ability to make a living. And viewing form this aspect, apprenticeship has relatively strong application and practicability, very closed with life. In addition, apprenticeship has no strict management system, only the oral agreement that people privately reach, and it regards morality as its main basic principle. The appearance of apprenticeship has boost the development of handicraft and brought the prosperous sight, which is closely tied up with apprenticeship.

\subsection{The characteristics of modern apprenticeship}

Higher vocational education belongs to the higher education, but the training objectives of our higher education are divided into two kinds: academic talents and practical talents. While higher vocational education is giving vocational education after mastering the demand of talent market, and only by this way can the talents meeting demand be trained for society. As far as from the aspect of practicability, there exist the same characteristics between the higher vocational education and traditional apprenticeship. Apprenticeship means that apprentices learn the practical skill of handicraft with the leading of masters, and higher vocational education also is oriented with the social practicability and the understanding with occupational demand of society to ensure the career goal of talent training. Although higher vocational education is developed on the basis of traditional apprenticeship, but higher vocational education has great difference with traditional apprenticeship. Higher vocational education has strict management system and distinct talents training plan and objectives, all of which are the characteristics that traditional apprenticeship doesn't have. So it is said that higher vocational education is the inheritance and development with traditional apprenticeship, and it has made up the deficiency of traditional apprenticeship to some degree so that making vocational education better play its role and promoting the development of educational career. Modern apprenticeship focuses on the relationship with enterprises, which is giving the "double teachers" education of school teacher and enterprise teacher.

\section{The Position of Higher Vocational Education}

If we want to study the talents training mode suited with higher vocational education, we must make the precise localization with the educational goal and effect of higher vocational education. Only mastering the educational goal and significant role in the educational career of higher vocational education can the appropriate talents training mode be worked out.

\subsection{Educational goal of higher vocational education}

At first, higher vocational education belongs to the higher education, viewing the training of advanced talents as its duty. And its educational goal is not same with college education and undergraduate college, mainly training the talents that society actually needs. Meanwhile, higher vocation is to train the occupational group meeting the social actual demand according to the precise localization with vocational training. As for the open courses and application of teaching method when giving the vocational education, they all have distinct plan and program. 


\subsection{Effect of higher vocational education}

Owing to the more and more important effect of teaching advantages and subject advantages of higher vocational education to the educational career. First, higher vocational education is the complement and improvement with education career of China so that forming the systematic educational system, and both of them try their best to make education career of China rapidly develop. Next, higher vocational education is one kind of vocational education, and it will adopt the scientific method to assess the occupational group needed by the social talents market to make the training of specific occupational group. And lots of majors, for example, current kindergarten teacher training and software project construction have become the professional courses of higher vocational education. Viewing from this aspect, higher vocational education has very significant effect on the aspect of adjusting the mismatching between supply and demand of market occupation. At last, higher vocational education is oriented with the practical major which is closed with the actual demand of society. Higher vocational education institutions train large amounts of professional talents for our country and make significant contribution for the vocational education of our country.

\section{The Existing Problems In The Higher Vocational Education}

Higher vocational education plays an important role in the educational system, so we must pay attention to the higher vocational education. There exists a variety of problems in the process of higher vocational education, which is conflicting with its goal. And the existing main problems in the higher vocational education is: narrow practical ground, limited practical time, not enough professional teachers and higher vocational education institutions lacking of the cooperation with enterprises so that it is hard to realize the integration of production, study and research.

\subsection{Narrow practical ground}

Higher vocational education regards the training of social practical talents as its main training objective, so it especially emphasizes the practicability and operational capacity of students. But higher vocational education usually exists the problem of narrow ground and limited time in the education process, making the practice of students hindered, even because of the narrow practical ground, the practical study of students will only be done in turn according to the time, which will result in that the practical study of students cannot effectively proceed and practical time will be cut down. All of them will hinder the practical ability study of students.

\subsection{Limited practical time}

Due to the limit of practical study and practical ground, the practical time of students is not enough, and as the higher vocational education institutions that regards the training of practical talents as its training target, although they cannot break away from the theory to practice, higher vocational education views the training of professional vocational group as its main goal. Thus, it should take time study on the basis of characteristics of all kinds of vocational groups, and only by this way can the talents that meet social demand be cultivated. The limit of practical time is the existing important question in the higher vocational education, so we must increase our attention to time and enhance the vocational ability of students.

\subsection{Profession of teachers is not enough}

As though higher vocational education has high requirement with the practicability of subjects, we cannot ignore the importance of theory. Therefore, the teacher group of higher vocational education should be equipped with solid theory and professional knowledge, and only by this way can the professional theory knowledge be taught to students. However, the teacher group in the current higher vocational education has the relatively low entrance standard, and teachers lack of profession, which makes the education goal of higher vocational education hard to be realized.

\subsection{Lack of the cooperation with enterprises}

Higher vocational education regards the market actual talent demand as its vocational training direction, so higher vocational education must increase its connection with enterprises, which can help to make the precise localization of the vocational demand and talent demand of market opportunity. 
However, the current higher vocational education lacks of the cooperation with enterprises and has no idea of the practical talents needed by the enterprise. Some colleges even cut out the cooperation with enterprises, holding the belief that students should steadily learn their own professional courses to the best, which is a very mistaken attitude, and we should change this attitude, increase the relationship with enterprises and train the talents that society actually needs through the training system of "double teachers".

\section{Solutions}

Next, I will put forward some feasible measures on the basis of the existing problems in the current higher vocational education. And only solving the existing problems in the higher vocational education can higher vocational education play the important role in the educational system and train useful talents for our country.

\subsection{Deepen the cooperation with enterprises}

Because that higher vocational education lacks of the cooperation with enterprises, so we must deepen the cooperation and communication with enterprises, and only by this way can the actual talent demand of enterprises be understood; meanwhile, the cooperation with enterprises will also provide a perfect platform for practice.

\subsection{Professional training system of vocation}

The teacher group of higher vocational education lack of speciality, so we must regularly train the teacher group of higher vocational education, and only by this way can the teacher group be guaranteed to timely update their own knowledge base, enhance their own teaching level and better teach students.

\subsection{Intensification of practicability}

Because of the narrow practical ground and limit practical time, the education goal of higher vocational education cannot be realized, so we must pay attention to train the practical ability study of students, making students early touch the related practical knowledge of vocational study, which can help to increase the social adaptability of students so that reaching the vocational time exercise.

\subsection{Formulate the talent training mode}

Higher vocational education needs to formulate the reasonable talent training mode, and only the reasonable talent training mode can train the talents meeting the social actual demand. Meanwhile, we should make the real-time supervision with talent training mode and guarantee the higher vocational education institutions to train the talent meeting social actual demand according to the talent training mode.

\section{Conclusion}

As the educational system of training advanced talents, higher vocational education is the evolution and promotion of traditional apprenticeship. Namely, higher vocational education is modern apprenticeship, with the "double teacher" teaching as its main characteristic, training lots of practical talents for society. There exists varieties of problems in the current higher vocational education; hence we must take the corresponding measures to solve the problems.

\section{Acknowledgements}

Fund Project: Henan Province Education Science "the 13th Five-Year Plan" Project in 2016: Study of Talents Training Mode of Modern Apprenticeship in the Higher Vocational Education. (NO.[2016]- JKGHB-0359).

Research Topic by Henan Social Science Association and Henan Province Federation in 2016: A Study on the Practical Teaching Model of "Mentoring" Based on School Enterprise Cooperation. (No. SKL-2016-2824). 


\section{References}

[1]. Jinfeng Yang. Research of talents training mode of modern apprenticeship in the higher vocational education[J]. Education Herald: electronic edition, 2017(3):6-7.

[2]. Wanyu Lu, Hongbin Wang. The construction of talents training mode of modern apprenticeship in Chinese characteristic higher vocational education[J]. Journals of Liaoning higher vocation, 2015.1(2013):21-24.

[3]. Zhihong Zhu. The exploration of talents training mode and practice of modern apprenticeship in the higher vocational education[J]. Technology pioneering monthly, 2014,27(5):117-118.

[4]. Tao Guo, Haidong lv, Binghu Sun. The exploration of talents training mode and practice of modern apprenticeship and practice research in the higher vocational education[J]. Heilongjiang Science, 2016, 7(11):62-63. 